\title{
ISSUES RELATED TO THE FINAL USE OF ETHANOL (FUEL AND CHEMICAL) \\ THE ALCOHOL - POWERED MOTOR: PAST, PRESENT AND FUTURE
}

Henry Joseph Jr.

Veja, a national weekly magazine, had the following news on its June $13^{\text {th }}, 1979$ issue:

"This time we won: CDE closed the case and Proalcool is now irreversible", as a close friend heard it from the Minister of Industry and Commerce, João Camilo Penna, ecstatic, upon exiting the meeting. In fact, $\mathrm{CDE}^{1}$ decided to invest 5 billion dollars in Proalcool ${ }^{2}$ until the end of President Figueiredo's term, in exchange for an equally grand figure: 10 billion liters of alcohol per year. With this volume, government expects to fulfill the additional demand for gasoline in the future, as well as completely fuel 475,000 vehicles with adapted engines plus 1.225 million of originally alcohol-fueled ones for the next six years.

The minister's euphoria on that moment was explainable for Proalcool - albeit having been created four years before by the previous General Ernesto Geisel government, by means of Federal Decree n. 76593 of 1975 - not having yet, according to the magazine, "left the realm of vague promises, far away from the path that could free Brazil from the petroleum nightmare".

Among the various problems that the program faced to replace gasoline with ethyl alcohol ${ }^{3}$, maybe the most significant one was to adapt engines to this new fuel with a minimum level of quality to

\footnotetext{
1 CDE (Conselho de Desenvolvimento Econômico) - Economic Development Council.

2 Proálcool (Programa Nacional do Álcool) - National Alcohol Program.

3 Ethanol and ethyl alcohol are synonyms; it is an alcohol with two carbon atoms in its molecule.
}

ensure performance and durability comparable to conventional gasoline-powered engines. Corrosion, high fuel consumption, impaired drivability and difficult cold starts were some of the factors that made mechanics frown with distrust upon vehicles converted to use alcohol.

Until then, only fleets in government and state-owned companies or taxicabs were authorized to convert their vehicles' engines to use fuel alcohol and results were not always satisfactory. The most numerous alcohol-powered fleet then belonged to one single company: the state-owned São Paulo telephone company (Telesp), which had 400 Volkswagen Sedan 1300 cars converted by Motorit, a firm specialized in engine reconditioning. These vehicles suffered from operational and durability problems, which required intense maintenance to be stubbornly used. Some other fleets were also being converted, however most vehicles converted for alcohol were taxicabs, which benefited from the allowance granted to buy alcohol at a $65 \%$ reduced price in comparison to gasoline at the so-called "licensed gas stations".

The alcohol fuel itself was, until then, from a technical specifications standpoint, reasonably unknown. Produced by different processes, in attached (connected to sugar mills) or independent distilleries (not attached), with variable chemical composition, it contained various contaminants from the processing, storage or transportation processes, plus an absurdly variable water content, that could range from $5 \%$ to $12 \%$ in volume, even considering only the so-called hydrated ethyl alcohol fuel. The issue then was whether the ideal ethyl alcohol 
for fuel should be produced according to specifications for pharmaceutical alcohol, food alcohol (used in the liquor industry) or sanitation alcohol (sold in supermarkets for household cleaning).

In fact, it should be remembered that the Department of Engines of the Aerospace Technical Center (Centro Técnico Aeroespacial - CTA), then led by the Air Force Coronel and Aviation Engineer Urbano Ernesto Stumpf (1916 - 1998), had been, since 1947, researching and developing the use of ethyl alcohol in internal combustion engines, with some success. Witnesses tell that, upon being presented a vehicle converted by CTA to use alcohol, President Geisel believed and decided that the program to use ethanol as an alternative fuel to gasoline was viable. Nevertheless, the works developed at CTA, while clustering the efforts of several engineers and technicians on some engines, only showed the technical feasibility of such conversion; they didn't take into account all the minor details that, in practice, would have to be considered, such as large-scale conversion of motors of different makes and brands, with different technical standards, plus varying conservation and maintenance conditions.

The reason for this difficulty in adapting engines to use alcohol for fuel was very simple: at that time, engine design resulted from decades of development in one technology (the internal combustion engine) for one specific fuel (gasoline); and vice-versa.

\section{THE DEVELOPMENT OF GASOLINE-POWERED ENGINES}

The motors-fuels match was one of the most important factors in the evolution and affirmation of the internal combustion engines market. In the first engines, still used for driving industrial machinery from the $19^{\text {th }}$ century, the fuel used was the same as in gas lighting ${ }^{4}$. The availability of this fuel, thanks to the public lighting systems of those days, made it very convenient for use in stationary engines ${ }^{5}$. Differently from the cumbersome steam engines with their furnaces, the reduced weight and size of the internal combustion engine made it quite attractive

\footnotetext{
4 Lighting gas was produced from coal gasification.

5 Industrial application engines, used to drive machines or electric generators.
}

for application in small vehicles that would serve for individual transportation. In this case, the use of lighting gas for fuel was inadequate.

The vision of the opportunity of its application to light vehicles led several entrepreneurs to work on adapting the internal combustion engines to liquid fuels. Their higher energy density and ease of transportation made evident the advantages of using this fuel in small vehicles.

The discovery of oil fields in the US, around 1854, with ample supply and relatively easy exploitation was another driving factor for this development. John D. Rockefeller, an American born in 1839, was one of the first visionaries to notice the business importance oil products would have as liquid fuels for those motorized vehicles that were beginning to appear. At the age of 22 he bought a small company, which got him into oil products refining, transportation and sales. In 1863, he founded his first refinery and the second one in 1866. He quickly secured the virtual monopoly of the business, building his own pipelines, buying several companies, developing distribution networks and using quick negotiation methods. In 1879, his Standard Oil Company controlled 95\% of the petroleum market. However, his efforts to enter the world of politics were not welcomed and, in 1892, with the Anti-Trust Law, his company was forced to divide into smaller enterprises.

The Austrian Siegfried Marcus is considered as the inventor of the carburetor, an essential part for using liquid fuels in internal combustion engines. Due to the natural difficulty to promote a good mix between liquids and air, the invention of the carburetor, by improving this mixture, brought an enormous advance to the use of gasoline as fuel.

Nevertheless, the final step in establishing the gasoline engine only came in 1883 with the work of Gottlieb Daimler and Wilhelm Maybach, who built a convincing operation carburetor and associated it to a fuel injection system they had also developed. The result was a tremendous leap in the evolution of internal combustion engines. Daimler's engine reached 900 RPM, while gas-powered motors of those days barely took on 200 RPM. This made the match between internal combustion engines and petroleum products, at the same time that it created conditions 
for developing the automobile, to which internal combustion engines became unavoidably attached.

However, the automobile would only be affordable to a few overly wealthy people, were it not for the entrepreneurial spirit of the American Henry Ford. Born in 1863, Henry Ford, an engineer, saw that the automobile could interest everyone, if only it could be bought for a reasonable price. In order to achieve a cheaper product, Ford invented the famous "assembly line", where all the production steps were spread along a belt conveyor, where each employee would mount a standard component. The idea was to gain in scale and avoid hesitation and time wasted by employees while building vehicles. Launched in 1908, and sold for 850 dollars apiece, the T-Model Ford was a hit and 15 million units were sold over some 20 years. Contrary to products offered by other manufacturers, Ford cars were not like handcrafted toys for the wealthy to show off; instead they were mass produced, to be used every day by plain citizens.

With the progress made by Ford and his many competitors, parts suppliers, resellers, repair shops, fuel stations and roads multiplied. Having a car, people were able to travel more and to live farther away from downtown areas. Pollution, noise, accidents and traffic jams replaced other urban problems and became thus associated to the image of urbanization and development.

So, at the outset of the $20^{\text {th }}$ century, from the introduction of the assembly lines and serial production concepts brought by Henry Ford, the automotive industry began growing immensely, not only in America, but also in England, Germany, Italy, and France. The year of 1919 reported the amazing figure of 186 roadworthy automotive manufacturers worldwide, which produced 11 million units in that year alone. The outbreak of World War I in Europe raised two very strong factors for this industry. On the one hand, it halted the growth this industry had been enjoying in terms of production volume, mostly in Europe, however, on the other hand, thanks to the war efforts and the widespread use of the internal combustion engine fueled with petroleum products in military cars and trucks, as well as in motorcycles, airplanes, boats, ships and any self-propelled contrivance, it caused tremendous technology leaps that allowed to improve their efficiency and performance, reduce their size and lower their cost.

In the period between the two World Wars, the number of vehicle manufacturers diminished, but the quantity of acquisitions and incorporations strengthened the surviving companies which, adopting more advanced technologies, resumed large scale production, rendering the automobile even more popular and taking this product to every corner of the planet. Intensely publicized by the movie industry, literature and press, the individual use of the automobile took on in every continent and country, transforming cities, opening highways, fostering oil prospecting, the construction of refineries and the distribution of products.

\section{THE DEVELOPMENT OF GASOLINE}

Contrary to the development of the internal combustion engine, whose major characters and dates are well known and documented, the development of features and specifications of gasoline as automotive fuel does not have the same accurate records and names. This is probably a result of countless minor empirical changes effected by hundreds of companies and technical associations throughout the past 100 years.

What can be said is that most of the early research into the adaptation of the physicochemical characteristics of gasoline to the requirements of internal combustion engines began in the US in 1900, due to the pressure exerted by vehicle manufacturers against the incredible variety of fuels offered to American consumers as proper for their vehicles. In 1982, when Standard Oil Company split into smaller companies and tens of other oil companies started out, the American oil refining industry began growing in such a haphazard manner, that each producer had their own criteria for fractioning petroleum into its various components. As petroleum is a mixture of tens of compounds (hydrocarbons) with different molecular sizes, separated by distillation in groups, the definition of where one group ends and another begins is essential, as each group will be named gasoline, diesel, kerosene, naphta, fuel oil, lubricating oil, grease or asphalt. For vehicle manufacturers, the variation in the mix of hydrocarbons present 
in the various "gasolines" available in the market was a huge problem, as such variation completely changes the physicochemical characteristics of the fuel, altering its combustion properties and compatibility with materials.

The outbreak of World War I (1914-1918) turned the need for setting quality standards and technical specifications for the most varied industrial products into an urgent issue and, within the action taken and nurtured by the US government, several technical associations were created. One such association was the National Petroleum War Service Committee ${ }^{6}$, which led to the creation of the American Petroleum Institute ${ }^{7}$ - API in 1919. In parallel, other existing technical standards associations became involved with developing norms for parts and components for the automotive industry, among them the American Society of Testing Materials ${ }^{8}$ - ASTM.

Also in Europe, the beginning of the $20^{\text {th }}$ century was a time for intense research and standardization of fuels and lubricants, with the involvement and creation of various standardization organizations, mostly in France, Germany, England and Italy. Just as in the United States, the two World Wars, both the First (1914-1918) and the Second (19381945) caused significant progress in the study of fuel properties and their specifications.

Therefore, within a 50-year interval that began circa 1900 and continued until the 1950s, engine, vehicle and gasoline were developed, each one to match the others, reaching excellent quality and compatibility levels, rendering the automobile the most suitable means of individual transportation, as well as an object of desire for any human being in the world.

\section{THE SEARCH FOR ALTERNATIVE FUELS}

When World War II burst, the automobile and vehicles of the same kind were already present in the four corners of the world and the demand for

\footnotetext{
6 War Effort Committee for National Petroleum (Comitê de Esforço de Guerra para o Petróleo Nacional).

7 American Petroleum Institute.

8 American Society for Testing and Materials.
}

fuel, components and replacement parts was quite significant. Interrupted supply of these products in non-manufacturing countries, due to transportation difficulties and rationing caused by the war, became a serious problem, leading to the search for alternative fuels and the rise of a new industry, the production of non-original parts, which later became the seed for new vehicle manufacturing centers in countries in Asia, Oceania and South America that until that moment did not have local manufacturing.

As the war ended, with the efforts to rebuild affected countries' economy, the United States taking the role of a new world power and the plans for rebuilding defeated nations, the automotive industry had its apogee. The automotive manufacturing park became international. Automobile, truck and parts manufacturing plants were implemented in dozens of countries, making the world fleet reach 200 million vehicles in 1960. Consequently, as all these vehicles were powered with gasoline or diesel, petroleum consumption hit 8 million barrels per day on that same year of 1960, at an average price around US\$ 2 per barrel at that time. Fuel was very cheap for those wonderful vehicles, which gave status, freedom and progress.

Conflicts in the Middle East, which began with the Suez War (1956) and that were deeply aggravated with the Six Day War (1967) were the first warning signs that oil-consuming countries saw about the possibility of shortage and price increases, making them think about their dependency on this energy source. On the other hand, oil-producing countries in that troubled area quickly realized they held a most valuable trading asset to impose their political interests on the international economic community. At that time, holding over $70 \%$ of the international oil trade, as the US production was short of supplying its own demand, the North Atlantic oil was outrageously expensive due to extraction in deep waters, Russia, the leader of the Soviet Union at that time, did not trade their oil with Western countries on account of the Cold War, Mexico and Venezuela were happy to fulfill part of the American oil production gap. As other countries had very little relevance in the existing oil trade, the Middle Eastern countries realized they held most of the supply for Western Europe, Asia, Oceania and a considerable part 
of the Americas in their hands. Taking power positions in the Organization of the Petroleum Exporting Countries - Opec, until then an existing but rather inexpressive international organization, they managed to compromise the producing countries into quotas and joint price setting. The results of this strategic union did not take long to be felt. In 1973, as a response to the international support given to Israel in the Yom Kippur War, the world was subject to what became known as the "First Oil Shock". The oil producing countries jointly cut their production volume and raised the price of the oil barrel to absurdly high values. In three months, oil price jumped from US $\$ 2.90$ to US\$ 11.65 per barrel. Such action shattered the world economy and led to severe recession in the US and Europe, with large international repercussion. Owning two-thirds of the petroleum reserves in the world, countries like Saudi Arabia, Iraq and Kuwait controlled production volume and prices.

The second petroleum shock occurred in 1979, caused by the Iranian Revolution that ousted Shah Reza Pahlevi and installed an Islamic republic in that country. Oil production in Iran was seriously affected and the nation was unable to supply even its own domestic needs. Iran, which had been the second largest Opec exporter, below Saudi Arabia, was practically out of the market. In short supply, oil price skyrocketed and increased the world economic recession in the early 1980s. Exception made to Iron Curtain countries (the Soviet Union and allies), which had the abundant Russian oil, all other countries, both developed and developing, were seriously affected by this shock.

The new oil price level after these two shocks and the joint action of the Opec countries, however, brought some unexpected consequences. Pressured by high prices, consuming countries sought new suppliers or resumed their extraction in known - but so far not economically viable - oil fields. Oil extraction in deep waters, in the North Sea, Gulf of Mexico, the Caribbean and the Brazilian coast, or inland extraction in Africa, Alaska and South America was then resumed and considerably increased the supply of petroleum.

On the other hand, this made it clear to the international community that the use of petroleum as a sole source of energy or raw material for producing vehicular fuel had to be reconsidered. Several experiments began to be carried out then in different countries. Methanol ${ }^{9}$, ethanol, vegetal oils, natural gas, $\mathrm{MTBE}^{10}, \mathrm{ETBE}^{11}, \mathrm{Fame}^{12}, \mathrm{FAEE}^{13}$, $\mathrm{DME}^{14}$ and various other substances started being mentioned and tried.

\section{THE USE OF THE GASOLINE - ALCOHOL MIXTURE}

Like gasoline, ethyl alcohol is also a light, flammable and easily obtainable liquid, so it also aroused interest as a possible fuel for vehicles by several early manufacturers. Were it not for the strong campaign against drinking in the US, in the early $20^{\text {th }}$ century (that culminated with the Prohibition Law, on January $16^{\text {th }}$, 1919), ethanol would probably have been used more often, or at least would have been further researched as fuel for vehicles. Henry Ford himself did experiments with an alcohol-powered T-model car in 1911, and several car races in the US Midwest between 1910 and 1915 used alcohol for fuel.

In Brazil, as ethyl alcohol was a lesser-valued product in sugar production, its informal use as fuel was quickly adopted for the first automobiles that arrived here, as a way to reduce the high cost of imported gasoline. On February $20^{\text {th }}, 1931$, through Federal Decree n. 19717, the government made it mandatory to add 5\% ethanol to imported gasoline and seven years later (Decree Law n. 737 of September 23 ${ }^{\text {rd }}, 1938$ ) - as the imported gasoline and alcohol mix results had been positive, and World War II had erupted in Europe - the government extended the mandatory addition of $5 \%$ ethanol to all gasoline sold in Brazil, regardless of its being domestic (local production had just begun) or imported.

\footnotetext{
9 Methanol and methyl alcohol are synonyms; it is an alcohol with one carbon atom in its molecule.

${ }^{10}$ MTBE - Methyl tert-butyl ether.

${ }^{11}$ ETBE - Ethyl tert-butyl ether.

${ }^{12}$ Fame - Fatty acid methyl ester (biodiesel made from transesterified methyl fat).

${ }^{13}$ FAEE - Fatty acid ethyl ester (biodiesel made from transesterified ethyl fat).

${ }^{14} \mathrm{DME}$ - di-methyl ether.
} 
However, the introduction of ethyl alcohol into our energy matrix in a responsible, standardized, consistent and systematic manner only began in the 1970s, by means of the National Alcohol Program (Programa Nacional do Álcool - Proálcool), which was implemented in two phases, named Proálcool I (Federal Decree n. 76593, 1975) and Proálcool II (Federal Decree n. 83700, 1979). Pressured by the strong impact on the Treasury caused by successive raises in international petroleum prices, the Brazilian government chose to make it official and add to our energy matrix the use of alcohol as automotive fuel. Though all the alcohol produced so far was ethylic, made from sugarcane, Proalcool's first idea was that other alcohols and other sources of raw material should also be fostered, such as methanol from natural gas or wood and ethanol from cassava.

At the same time and for the same reasons, other countries also focused on the implementation of research programs for alternative fuels, among them methanol (United States, South Africa, Germany, Japan etc.) and ethanol (Sweden, India, China, Australia etc.). Like Brazil, these countries also saw in alcohols a cheap and adequate alternative to petroleum products.

In its first phase, Proálcool did not have a clear goal on how alcohol should be used, if only as an admixture to gasoline or if it should also be used pure in converted engines like the one shown by CTA to President Geisel. It was known that, as an admixture to gasoline, ethanol should be of the anhydrous type ${ }^{15}$, since the presence of water impaired miscibility, especially in colder environments, causing the two fuels to divide into two phases. On the other hand, to be used pure in adapted engines, it was understood that hydrated alcohol $^{16}$ - for its being cheaper and more abundant (few distilleries then had the second tower, required to produce anhydrous ethanol from hydrated ethanol) - was more adequate.

\footnotetext{
15 Anhydrous ethanol is obtained from hydrated ethanol, by a second distillation after the addition of a co-solvent, which helps remove remaining water.

${ }^{16}$ Hydrated ethanol is the result of the first distillation of the fermented sugarcane juice, which contains $6 \%$ to $9 \%$ of water remaining from the fermentation process.
}

At that time, the National Petroleum Council (Conselho Nacional do Petróleo - CNP), was the agency in charge of technical specifications for fuels, so it was also assigned the task of specifying methanol, anhydrous ethanol and hydrated ethanol. Since the production of methanol was not significant and its use for fuel had been under international criticism (fire hazards due to its invisible flame and the risk of intoxication if ingested), the specification of this product was postponed to a second stage. Regarding ethyl alcohol, lacking a deeper knowledge on its automotive applications, CNP initially adopted the prevailing specifications for other uses, as pharmaceutical alcohol, alcohol for beverage production or sanitation (cleaning) alcohol.

CNP also adopted regional limits for adding alcohol to gasoline, raising the content to 10\%-15\% in the alcohol-producing states (10\% to $11 \%$ in Pernambuco, $11 \%$ to $12 \%$ in São Paulo, 11\% to 15\% in Alagoas, $10 \%$ to $15 \%$ in Paraná and $10 \%$ to $12 \%$ in Rio de Janeiro, Ceará, Rio Grande do Norte and Paraíba), keeping a minimum of $5 \%$ for all others.

The presence of ethyl alcohol in gasoline changes several of the latter's physicochemical characteristics, such changes being somewhat more significant, the more alcohol content in the final mix. Up to certain limits in this mix, vehicles that were not developed and designed for alcohol-bearing gasoline will function without any major trouble, as safety margins used in their design, plus manufacturing and tune-up adjustments will tolerate minor deviations in the characteristics of the fuel used. However, when these deviations escalate, proper functioning of the vehicle may be compromised, and performance, drivability and durability failures may occur. There is no set limit between one situation and the other, as it depends a lot on the type, model, brand, technology level, use and maintenance condition of the vehicle in question. It also depends on the quality and specifications of both the gasoline and alcohol used, as well as occasional contamination (accidental or deliberate) that either one or both may have. In some cases, environmental conditions (temperature, humidity and pressure) during use may also influence functional outcomes.

Generally, upon specifying the physicochemical features of a fuel, regulatory agencies focus on three different sets of characteristics: 
1. The first set covers those properties that ensure quality as a fuel per se and which are also considered by vehicle manufacturers' engineers upon designing and developing engines. In the case of gasoline, some examples of these characteristics are density, octane rating, distillation curve, vapor pressure, oxygenated compounds content and heating value - important items to define vehicle performance and engine parameters, such as compression rate, fuel/air ratio, cooling, lubrication, as well as starting systems rating, fuel injection systems calibration, ignition system mapping, valve opening control definition, metal load on the catalytic converter, lubricating oil specification and so on.

2. The second set deals with properties that ensure the origin and quality of the fuel production process, important for defining metallic parts, possible metallic parts coating protection; polymers, elastomers and adhesives used in the fuel tank, filters, and pumps, injection system, hoses, sealing rings, exhaust system and any parts that may come in contact with the fuel. These are also important to prevent buildup of residues that may obstruct the fuel line, or cause sedimentation in tanks, filters or combustion chambers, as well as to avoid poisoning the catalytic converter. For gasoline, examples of these characteristics are lead content, sulphur content, copper strip corrosion, stability to oxidation, gum content (washed and unwashed), hydrocarbons content (benzene, aromatic, olephinic, naphthenic), end point and residue of distillation and the presence of detergent additives.

3. The third set focuses on the need for fuel inspection to control its distribution and sale, important to enable authorities responsible for the final fuel quality to prevent occasional deviation, fraud, contamination and improper usage. On the other hand, these characteristics (within proper limits) do not influence vehicle performance, operation nor durability. In the case of gasoline, this class includes the definition of color and appearance.

Due to lack of further knowledge, upon adopting the first specifications for ethanol fuel (both for hydrated ethyl alcohol fuel - AEHC and for anhydrous ethyl alcohol fuel - AEAC) and for the alcohol-gasoline mixture, CNP failed to assess the consequences of introducing this new fuel and, therefore, did not set limits that could inhibit significant changes to the final quality of the gasoline sold.

Even considering that automotive engines in those days - due to the available technology and less stringent requirements on fuel consumption and pollutant emissions - had coarser calibration and tuning than present ones and that they could cope with wider variations in fuel characteristics, the use of gasoline containing up to 15\% anhydrous ethanol caused the occurrence of several problems. Difficult start, loss of power, torque and drivability, clogged nozzles, sediment buildup and erratic idling speed were the most persistent initial complaints. After a while, more serious grievances began to come up, including sudden failure, hydrolock ${ }^{17}$ and parts corrosion. At this time government realized the seriousness of the situation and began suggesting vehicle owners and manufacturers to adjust engine tuning to take into account the presence of ethanol.

After many trials and errors, CNP began adopting more adequate specifications for the ethanol admixture to gasoline, setting minimum and maximum ethanol content levels in the gasoline admixture $^{18}$, as well as considering the influence of the ethanol present in specifying other characteristics for gasoline, and adopting a specification for pure gasoline before anhydrous gasoline were added (Atype gasoline), and a new one for gasoline already containing ethanol (C-type gasoline).

${ }^{17}$ Hydrolock is caused by flooding the combustion chamber with liquid fuel, due to its directly passing through the fuel feeding system; due to the effort caused by the attempt to compress a liquid, pistons, rods, crankshaft and head are damaged.

18 Several ranges were successively adopted (18\% to 20\%, 20\% to $23 \%, 23 \%$ to $25 \%, 18 \%$ to $22 \%, 10 \%$ to $12 \%, 13 \%$ to $17 \%, 17 \%$ to $23 \%$ and $21 \%$ to $23 \%$ ) until an adequate balance was found between specification, ethanol supply, and calibration range. 
On another front, based on better understanding of the physicochemical characteristics required to use ethanol as fuel, both $\mathrm{AEAC}$ and AEHC were specified in a more adequate way. Limits for density, alcohol content, total acidity, fixed residues and copper content were included or modified, to improve compatibility with gasoline and the vehicles.

Several institutions collaborated in this work, some of them being Cepat ${ }^{19}$, IPT ${ }^{20}$, INT ${ }^{21}$, CTC ${ }^{22}$, Cenpes $^{23}$, Abiquim $^{24}$, ABNT $^{25}$, Abraco $^{26}$, Anfavea ${ }^{27}$, Sindipeças ${ }^{28}$, Sindicom ${ }^{29}$, Sopral ${ }^{30}$ and various producers of fuel, lubricants, automotive vehicles, auto parts, laboratory instruments etc.

As specifications for gasoline were progressively improved, embodying the necessary changes due to the presence of alcohol, it became possible to develop more adequate auto parts, as well as calibration and tune-up concepts. The domestic automotive industry itself gradually began to

${ }_{19}$ Technology Research and Analyses Center of the National Petroleum Council (Centro de Pesquisas e Análises Tecnológicas do Conselho Nacional do Petróleo).

${ }^{20}$ Technology Research Institute of the São Paulo State University (Instituto de Pesquisas Tecnológicas da Universidade de São Paulo).

${ }^{21}$ National Technology Institute of the Ministry of Science and Technology (Instituto Nacional de Tecnologia do Ministério de Ciências e Tecnologia).

${ }^{22}$ Copersucar Technology Center (Centro de Tecnologia da Copersucar - today, Centro de Tecnologia Canavieira).

${ }^{23}$ Petrobras Research Center (Centro de Pesquisas da Petrobras).

${ }^{24}$ Brazilian Chemical Industries Association (Associação Brasileira das Indústrias Químicas).

${ }^{25}$ Brazilian Technical Standards Association (Associação Brasileira de Normas Técnicas).

${ }^{26}$ Brazilian Association of Studies in Corrosion (Associação Brasileira de Estudos da Corrosão).

${ }^{27}$ National Association of Automotive Vehicles Manufacturers (Associação Nacional dos Fabricantes de Veículos Automotores).

${ }^{28}$ National Syndicate of Automotive Vehicle Parts Industry (Sindicato Nacional da Indústria de Componentes para Veículos Automotores).

${ }^{29}$ National Syndicate of Fuel and Lubricant Distributing Companies (Sindicato Nacional das Empresas Distribuidoras de Combustíveis e Lubrificantes).

${ }^{30}$ São Paulo State Alcohol Producers Association (Sociedade dos Produtores de Álcool do Estado de São Paulo). implement these modifications, making their cars leave their plants already suited to the fuel available in the marketplace. On the other hand, auto parts manufacturers began to make available, for the replacement market, components already including the modifications auto makers were implementing. Many auto repair shops began to get qualified for altering and tuning vehicles in use with the necessary changes for using the new fuel. It can be said that over a three to five-year period most of the Brazilian fleet of gasoline-powered vehicles had been enabled to use C-type gasoline.

\section{ALCOHOL-FUELED ENGINES}

Beyond the increase of the alcohol content in gasoline, one of the Proálcool goals in 1975 was to stimulate the use of ethanol alone as fuel, i.e, cars running on $100 \%$ ethanol.

Enthusiastic over the demonstration by engineer Urbano Stumpf to President Ernesto Geisel, the Brazilian government felt that it was possible to stimulate the population to convert their cars to run on $100 \%$ alcohol, if this fuel were priced lower than gasoline and if the conversion were made by licensed shops at an affordable cost. This would increase the replacement of gasoline by ethanol, saving more money for the country.

The conversion of an engine from gasoline to ethanol, as it had been done in the CTA, was based on theoretical concepts already available in the international academic literature, many of them originally from experiments carried out by Henry Ford back in 1911. Actually, the work developed at CTA conceived the major modifications to be made to a gasoline-powered Otto cycle engine, required to use ethyl alcohol for fuel: air-fuel ratio changed to a new stoichiometric level (from 14.5:1 for pure gasoline to 8.5:1 for hydrated ethanol), ignition spark advanced further, use of spark plugs with wider thermal range, increased flow rate from the fuel pump and gasoline spray injection to aid cold starting.

Such modifications, when performed on an engine by qualified technicians, by means of accurate calculations and measurements done with engineering resources, led to very satisfactory results, in both operational and dynamic performance terms. 
However, the Brazilian government's intent was to have engine conversions widely performed by auto shops that, in spite of being certified and staffed with good technicians, did not have the resources needed to treat each engine individually. Therefore, no means were available to make an initial assessment of a vehicle to be converted, considering the technical features and the maintenance condition of its components to allow, by means of calculations, the definition of new settings for the carburetor, distributor and fuel pump. Consequently, as customized handling of each vehicle was impossible, modifications were made on a general basis and results were not always satisfactory.

On the other hand, conversion research made by the CTA focused only on the engine's functional and performance aspects, which were certainly the most important at the outset. However, little, if any, attention was given to fuel quality aspects or engine parts durability, which has a huge mid - and long-range impact and this may negatively affect the way the conversion is perceived.

Furthermore, specifications that had been adopted for both anhydrous and hydrated ethanol were still insufficiently adequate, which allowed for tremendous variations in the content of several contaminants that were later identified as the cause of ethanol's corrosive attack.

Hence, the initial image of 100\% hydrated ethanol as a fuel was not very positive in the eyes of the public and the press. On one side, we had poorly converted vehicles, with bad performance and parts unsuitable for contact with ethanol. On the other side, we had a quite aggressive fuel with very inconsistent quality. The result was some vehicles displaying absurdly high fuel consumption, despicable drivability, clamorous starting problems especially in cold weather, that issued a pervasive odor and that required constant repairs to the fuel feed system, due to corrosion and sediment buildup.

The period between Proálcool I (1975) and Proálcool II (1979) was decisive for the success this fuel had in the next years.

During this period, several studies were carried out to determine the reasons for the corrosiveness of ethanol, which allowed new specifications to control some major features. Therefore, to comply with the new specifications, ethanol producers had to alter their industrial processes, resulting in improved and more consistent quality.

To improve the program image, the government understood that it was necessary to convince auto manufacturers, which had been adapting their cars to use the gasoline-alcohol mix, to offer original factory alcohol powered vehicles. Their belief was that consumers would feel more secure using this fuel, mostly because of the manufacturers' warranty. They also believed that car manufacturer engineers would be able to solve several of the existing technical problems. For this purpose, government representatives had meetings with the Vehicle Manufacturers' Association (Associação dos Fabricantes de Veículos Automotores - Anfavea) and, in 1979, a covenant was signed setting a production commitment ${ }^{31}$ regarding wholly-alcohol fueled vehicles to be launched on the following year.

The entrance of auto manufacturers in the development of engines specifically for alcohol drew the line that divided the technology used until then by conversion shops from the one that was thereon built into the new vehicles.

The main changes made to the new vehicles built for the new fuel were:

a. In the carburetor (at that time there were no Brazilian-made vehicles with electronic fuel injection), the lid received surface treatment (phosphatization, chrome plating, nickelization, chemical nickel plating or anodization) to avoid direct contact of the base metal (aluminum or Zamak ${ }^{32}$ ) with ethanol, the float hinge was replaced (changed from carbon steel to brass or nickel plated brass), the float material was changed (from Ebonite ${ }^{33}$ to polyamide 11), plastic inserts were replaced with metallic ones (from polyamide 6.6, to copper or

31 250,000 vehicles in 1980, 300,000 vehicles in 1981 and 350,000 vehicles in 1982 .

${ }^{32}$ Metallic alloy of aluminum, zinc and manganese.

${ }^{33}$ Ebonite $^{\circledR}$ - Vulcanized spongy rubber with high sulphur content. 
bronze) and the high-speed valve menbrane was changed (from nitrile rubber to Viton $\left.^{34}\right)$.

b. The air-fuel mixture was adjusted to a leaner ${ }^{35}$ ratio by replacing the nozzles ${ }^{36}$ in the carburetor.

c. The fuel tank (at that time tanks were made from phosphatized or galvanized iron plates, sealed with epoxy resin) thereon received an internal surface treatment (brass or lead plated) and had its volume capacity enlarged, to be more compatible with the increased fuel consumption inherent to ethanol.

d. The fuel pump received similar treatment to that made to the internal surfaces of the carburetor, carbon steel clamps were replaced with brass ones, and the natural rubber menbrane was replaced with a nitrile rubber one.

e. The fuel filter had to host a new filtering element, sealed with synthetic glue, not soluble in ethanol.

f. The intake manifold was redesigned into a profile that allowed increased flow and internal walls were treated for lower rugosity.

g. Compression ratio in the combustion chamber was significantly increased, from 7 8:1 to 9 11:1; consequently, the engine block and head reinforcement structures had to be redesigned.

h. Ignition timing had to be advanced further so that spark occurred earlier and spark plugs were replaced with others having lower temperature ranges.

i. The valve command camshaft was given a new cam profile and new phases, changing the timing of opening and closing of admission and exhaust valves; the valves

\footnotetext{
${ }^{34}$ Viton $^{\circledR}$ - fluorinated rubber.

35 "Lean" is the designation given to an air-fuel ratio where there is excess oxygen for the quantity of fuel introduced as vapor in the combustion chamber.

${ }^{36}$ Metallic parts fitted with a precision hole, that work like mini-venturis, i.e., they impose a restricted maximum flow rate for a fluid going through.
}

themselves and their seats received new harder surface materials.

j. The exhaust pipe and muffler assembly received internal surface protection and its design was altered to prevent the accumulation of condensed water from the exhaust gases, produced in larger quantity when burning ethanol.

k. Lubricating oil was changed to a new additive package, more compatible with ethanol usage.

1. The vehicle was fitted with a cold start aid system, which sprays a small quantity of gasoline vapor directly into the intake manifold, fitted with a temperature probe, a small gasoline tank and its own electric pump and fuel injector.

It can be said that the outcome of these changes was very positive, even considering that they were not simultaneously adopted in all of the aforementioned components, nor by all vehicle manufacturers. However, the negative image converted cars had gradually faded and consumers became interested in alcohol-powered cars.

Even with the adoption of a Fuel Saving Program (Programa de Economia de Combustível Peco) in 1981, emission limits set by Proconve (in 1986) and with the incorporation of new automotive technologies such as electronic fuel injection (in 1987), the EGR exhaust gas recirculation (in 1992), plastic fuel tanks (in 1994), and catalytic converters (in 1997), the technical concepts adopted for using ethanol were maintained and improved.

After several successful years, with over five million alcohol-powered vehicles manufactured from 1979 through 1993, considering that in 1986 the sales of 700,000 alcohol vehicles represented $89 \%$ of the light vehicles sold, consumers interest for this fuel declined. In 1995 less than 50,000 units were sold and in 1997 only $0.1 \%$ of the total light vehicles sold were alcohol-fueled.

There was not one single cause alone. Various factors got together to reduce consumers' interest in alcohol vehicles: the international price of petroleum went down, allowing a reduction in the price of its products; the international price of 
sugar went up, leading producers to prefer exporting sugar; Brazilian government offered incentives to the production of popular vehicles without any incentive to their engines being alcohol-fueled, which led manufacturers to launch gasoline-fueled popular cars only.

Nevertheless, the launch of flex-fuel vehicles, in March 2003, was a historic milestone and a turning point in the Brazilian alternative fuels market.

After the launch of the flex-fuel car, popularly known as bi-fuels, the Brazilian automotive industry manufactured in little over five years (from March 2003 through December 2008) 6.95 million of flex-fuel cars. Nowadays, 11 manufacturers offer over 70 different models of flex-fuel cars in the Brazilian market, their price being equivalent to conventional models.

Actually, flex-fuel vehicles were not invented in Brazil. The first vehicles fitted with technology for different fuels were introduced in the United States in the 1980s. However, the technology used by US manufacturers is based on a fuel identification probe, which analyses the fuel being used, and then gives an input signal to the onboard computer to adjust the injection and ignition systems to the best burning conditions for that fuel. In spite of its efficiency, this technology is expensive, and completely dependent on the useful life of the probe. Due to its cost, this technology can only be implemented in expensive vehicles, so as not to increase significantly the cost to the end user. In the US, this technological concept's success was only due to the interest of manufacturers in offering a vehicle powered by an alternative fuel so they could benefit from tax incentives.

As the Brazilian market is dominated by lowcost compact vehicles, it is unthinkable to adopt the expensive American flex-fuel technology in Brazil. Therefore, when Brazilian car manufacturers began discussing the possibility of launching such vehicles locally, the basic requirement was to develop a new concept that avoided the need for a fuel sensing probe.

At this point, Brazilian creativity and the vast experience brought together over 25 years manufacturing $100 \%$ alcohol-fueled vehicles came out loud and clear.
Based on the existing differences in two physicochemical characteristics of alcohol and gasoline (octane rating and stoichiometric ratio) and using the same diversified probes that all modern vehicles already have (pressure and air temperature, fuel flow rate, load, rotation speed, engine firing and oxygen content in the exhaust gas), Brazilian engineers developed a completely new flex-fuel system. In the Brazilian system, fuel is first burnt in the ignition chamber and, a split of a second later, evaluating the consequences of that explosion via the existing sensors and comparing it to a resident database in the onboard computer memory, it is possible to analyze the fuel and adjust the engine settings, without the need for a fuel identification probe. This renders a flex-fuel vehicle for the same price as an alcohol vehicle, which we had learned to manufacture so well.

Thanks to the overwhelming acceptance of flex-fuel engines and to the competitive price of hydrated alcohol, the declining Brazilian production of alcohol took a tremendous thrust and thereon began growing at a rate above 10\% per year.

\section{THE FUTURE OF ALCOHOL ENGINES}

The expression "renewable fuel" is used to define fuels made from agricultural products or from organic matter fermentation. Contrary to fossil fuels (petroleum and natural gas) that will be over when reserves are exhausted, mankind will always be able to produce more renewable fuel as needed.

However, there is yet another peculiarity that adds meaning to renewable and that has pointed biofuels as the savior solution for global warming. It is the fact that the $\mathrm{CO}_{2}$ gas emissions from burning any fuel (and being the major cause for atmospheric heating) is reabsorbed via photosynthesis by the same plants used to produce renewable fuels, almost neutralizing their use. Thus, the $\mathrm{CO}_{2}$ emissions are recycled, leaving no negative effect to the environment.

Due to features such as their easy application to existing automotive technologies, by replacing the ailing and expensive petroleum and by their lower environmental impact, renewable fuels made from biomass have been conquering space and 
leading other countries into becoming interested in their use.

Just as there are countries interested in using renewable fuels, there are countries eager to produce them for export, as their climate and geography favors agriculture and they see such production as an economic opportunity.

Therefore, one can envisage a forthcoming international market for renewable fuels, creating socio-economic opportunities for many countries and energy options for others, at least until a new vehicle concept is developed - cleaner, more affordable and more reliable - to be mass-produced and eventually replaces the current internal combustion engine cars.

So what are the most promising technologies under development?

Basically, ongoing studies point in the same direction, which is the use of electric motors, as they are efficient, silent, powerful, non-polluting and simple. However, there are still two pending issues: how electricity can be generated to power these motors in a safe and non-polluting way and how this energy can be taken on board in a sufficient quantity to offer some good autonomy. Generating energy in a safe and non-polluting way goes through the risk analysis over thermal or nuclear power plants and taking enough stored energy on board means anything other than carrying the well-known and heavy battery using lead or other heavy metals.

Current beliefs consider that the most adequate way to generate electric power would be through the ion exchange obtained by passing hydrogen though an array of electrolytic membranes (the so-called fuel cell), coupled with a catalytic transformer able to extract hydrogen from a substance with a high content of this gas, such as natural gas (methane rich), or, preferably, due to the ease of supply and transportation, from a liquid, such as an alcohol (methanol or ethanol). Due to its extremely low density and high explosion power, the idea of transporting cylinders filled with hydrogen gas on the vehicle is being avoided.

As it may have been noticed, Brazil continues to be a privileged country in the vehicle technology future, since the use of alcohol to generate hydrogen, which in other countries is methanol, obtained from natural gas (hence fossil and finite) or wood (low yield), in our case will be ethanol from sugarcane, which we know how to make like nobody else.

Putting it all together, there is a very promising big picture. We are replacing our fleet with flex-fuel cars, which can use gasoline or alcohol, so we can shift from one fuel to the other depending on price and availability. We are also introducing vegetal oil admixtured to diesel, which will reduce our dependency on petroleum, as soon as biodiesel production attains sufficient scale. Albeit being technologically behind, other countries are following a similar path, which will lead to an international market of renewable fuels, giving Brazil more energy security and opening space for further developments. Due to its sustainability features and for pooling together solutions for economic, social and environmental issues, as well as reducing emissions that cause global warming, the renewable fuels market will be quite attractive to international investors. There is an immense application potential for renewable fuels in the future vehicle technologies. We became self-sufficient in petroleum production and yet we have natural gas available to be included in our energy matrix.

Contrary to those countries that fear an energywise complex future, Brazil has the opportunity to make better use of its energy matrix, both for itself and for export. 